\title{
Improving selenium status in plant nutrition and quality
}

\author{
M. L. Mora ${ }^{1 *}$, P. Durán ${ }^{1}$, A. J. Acuña, P. Cartes ${ }^{1}$, R. Demanet ${ }^{1}$ and L. Gianfreda ${ }^{2}$ \\ ${ }^{1}$ Center of Plant, Soil Interaction and Natural Resources Biotechnology, Scientific and \\ Biotechnological Bioresource Nucleus, Universidad de La Frontera, Temuco, Chile. ${ }^{2}$ Università \\ degli Studi di Napoli Federico II, Naples, Italy. *Corresponding author:mariluz.mora@ufrontera.cl
}

\begin{abstract}
Selenium (Se) is an essential micronutrient for human health due to its antioxidant capabilities. The Se content around the world is highly variable from $0.005 \mathrm{mg} \mathrm{kg}^{-1}$ in areas from China and Finland to $8,000 \mathrm{mg} \mathrm{kg}^{-1}$ in seleniferous soils from Tuva-Russia. However, about one billion of people in the world wide are Se deficient.

During the last decade, studies related with strategies for Se biofortification in food plants for human nutrition have significantly increased because this metalloid is incorporated into human metabolism mainly as a constituent of food plants. Similarly, Se biofortification is important in pastures for increasing the Se content in cattle to enrich meat and to prevent disease associated to Se deficiency as white muscle disease. In China, two endemic diseases have been related to Se deficiency: Keshan and Keshin-Beck diseases.

Agronomic biofortification by using inorganic Se sources is a current practice in countries as China, Finland, and USA. In Chile, fertilization by using chemical compounds with $\mathrm{Se}$ is an uncommon practice due the edaphoclimatic characteristics of Andisols, which represent around $60 \%$ of agricultural soils of southern Chile. Recent studies showed that microorganisms as bacteria and arbuscular mycorrhizal fungi play an important role in the transformations and Se availability, representing an interesting biotechnological alternative to Se biofortification.

This review is focalized to describing Se behavior in soil-plant system and the possible strategies to improving Se content, including the use of microorganisms as biotechnological tools for increasing plant nutrition and quality. Specific attention will be devoted to volcanic soils of Southern Chile, where different factors concur to enhance the Se-deficiency problem.
\end{abstract}

Keywords: Selenium, Andisols, Selenobacteria, Biofortification 


\section{Introduction}

Selenium (Se) is a naturally occurring chemical element found almost everywhere on earth. During several years, this metalloid has been considered toxic and dangerous for human and animal health (O'Toole and Raisbeck 1995). Only in the last decades, its physiological importance as a micronutrient fundamental to animal and human health has been assessed (FernándezMartínez and Charlet, 2009). The essentiality of Se has been established when this metalloid has been recognized as a constituent of selenoenzymes such as glutathione peroxidase (GSH$\mathrm{Px}$ ), thioredoxin reductases (TR), and proteins with unknown functions that are involved in maintaining the cell redox potential (Rayman, 2000). Nowadays, 25 selenoproteins have been described in human metabolism, corresponding to selenoproteins in which $\mathrm{Se}$ is an enzymatic cofactor (Korlhe et al. 2000; Dodig et al., 2004; Rayman, 2000; Schomburg et al. 2004). Thus, Se deficiency increases the risk of oxidative damage and important associated pathologies, i.e. cancer and HIV (Facompre and El-Bayoumy, 2009; Méplan and Hesketh, 2012).

While selenoproteins have been discovered for bacteria and animals (and for many of them it has been identified their physiological role), experimental attempts made to recognize these proteins also in plants have so far failed and this question remains unresolved. However, studies realized by Pilon-Smits et al. (2009) showed that Se in plants improves the plant growth, increases the tolerance against biotic and abiotic stress (Hartikainen and Xue, 1999; Xue and Hartikainen, 2000; Pennanen et al. 2002) and improves other physiologic parameters (Xue et al. 2001; Djanaguiraman et al. 2004; Turakainen. 2006).
This is interesting because the main source of Se nutrition for humans and animals is the soil-plant system, and a mineral imbalance can lead to Sedeficient food with consequences for human and animal nutrition (Govasmark and Salbu, 2011). Plant foods are the major dietary sources of Se in most countries throughout the world (Rayman et al. 2008). The amount of Se available in soil, determines the amount of Se in the plant foods that are grown in this soil. The awareness that the intake of plants with desirable, non-toxic Se levels is the first step of Se entry in the food chain could explain why biofortification of this element has received great attention. For instance, field treatment with Se or Se rich-compounds can be considered a safe, low cost approach to achieve this target in Se deficient areas (de Souza, 1999; Ingh, 2005).

This review will address the complexity of Se behavior in plants and soils with particular reference to Se deficient soils and the possible strategies to improving Se content including the use of microorganisms capable to metabolize the inorganic Se for their use as seed inoculants for plant nutrition and quality. Specific attention will be devoted to volcanic soils of Southern Chile where different factors concur to enhance the Se-deficiency problem.

\section{Quality of selenium supplemented plants}

Plants are constantly and frequently exposed to the effects of reactive oxygen species. These free radicals are very reactive species producing oxidative stress, which results in internal $\mathrm{H}_{2} \mathrm{O}_{2}$ accumulation. Oxygen peroxide may act as signaling molecule and induce a sequence of reactions 
and/or provoke unspecific oxidation of proteins, membrane lipids or DNA injury. As well described in mammals and humans, and very likely in plants, several enzymatic (e.g. superoxide dismutase, SOD, glutathione peroxidase, GSH$\mathrm{Px}$, catalase, CAT, guayacol peroxidase, POD, ascorbate peroxidase, APX) and non-enzymatic (e.g. ascorbate, glutathione and vitamin E) actors participate to this mechanism (Miller et al. 1993). Hartikainen et al. (1997) investigated the antioxidant effect of Se in lettuce (Lactuca sativa) and ryegrass (Lolium perenne) plants. The activity of GSH-Px increased in both plants at doses of Se increasing from 0 to $33 \mu \mathrm{g} \mathrm{kg}^{-1}$. Later, Hartikainen et al. (2000) demonstrated the duality of Se effect depending on the applied Se doses. At low concentrations $\left(0.1,1.0,10 \mathrm{mg} \mathrm{Se} \mathrm{kg}^{-1}\right)$ Se behaved as antioxidant, whereas ad elevated concentration (30 $\mathrm{mg} \mathrm{Se} \mathrm{kg}^{-1}$ ) it acted as pro-oxidant. It was hypothesized that while Se decreases the oxidative stress by increasing the activity of GSH-Px, which in turn reduces the levels of hydrogen peroxide, it can itself induce the spontaneous dismutation of the anion superoxide, thus diminishing the need of SOD action. This latter catalyzes the dismutation of the superoxide anion (that initiates a cascade of reaction of free radicals) to hydrogen peroxide (Mittler and Zilinskas, 1991). Sabeh et al. (1993) measured GSH-Px activity in purified Aloe vera extracts and proposed that this enzyme was a tetrameric protein with one atom of Se per subunit. In a study on the antioxidative properties of Se during photoxidative stress in potato, Seppänen et al. (2003) demonstrated the Se altered transcript accumulation of GSH-Px. Similarly, Cartes et al. (2005) evaluated the effect of selenite and selenateon the GSH-Px activity and lipid peroxidation. Thus, for both Se sources, there was a positive correlation between Se shoot concentration and GSH-Px, and lipid peroxidation measured by Thiobarbituric Acid Reactive Substances (TBARS), decreased at low level of Se shoot concentration. Similarly, Cartes et al. (2011), showed a reduction of oxidative damage in membrane ryegrass cv Aries and Nui by an activation of GSH-Px antioxidant enzyme, demonstrating the Se essentiality to plants due its significant role as antioxidant in plants.

Another important cause of oxidative stress is exposure to UV-B radiation, nowadays one of the major concerns to plant biologists. Several studies and contrasting results have been obtained on the combined effect of Se and UV-B radiation on plants. Hartikainen and Xue (1999) evaluated the Se effect on the growth and the membrane damage in plants exposed to UV-B radiation. It was also observed that the UV-B radiation diminished the toxic effect due to high doses of Se supplied. Similar study has been carry out in lettuce (Pennanen et al. 2002) and pumpkin (Germ et al. 2005). Heijari, (2006) observed that Se did not decrease the harmful effects of UV-B radiation in strawberry and only an increase of leave development occurred at low dose of Se $\left(0.1 \mathrm{mg} \mathrm{kg}^{-1}\right)$.

Additionally, it is been also postulated that $\mathrm{Se}$ can contribute to decrease plant senescence and increase plant growth. One of the first beneficial effect of Se on plant growth was recorded by Singh et al. (1980), who observed that the ap-

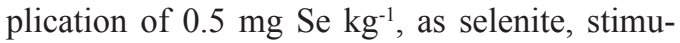
lated the growth and the production of dry mass in Indian mustard and ryegrass, lettuce, potato and duckweed (Hartikainen, 2005). Thus, the main physiological benefits of Se in plants can be summarized as follow: enhancement of plant growth (Hartikainen et al. 1997; 2000); delay of 
plant senescence (Xue et al. 2001; Djanaguiraman et al. 2004); increase in carbohydrate accumulation (Turakainen, 2006); improved tolerance to photoxidative stress (Seppänen et al. 2003, Cartes et al. 2005; 2006; 2011); alleviation of abiotic and biotic stresses such as UV-B radiation (Hartikainen and Xue, 1999; Xue and Hartikainen, 2000; Pennanen et al. 2002) cadmium.(Filek et al. 2008; Pedrero et al. 2008) and fungal infection and herbivores (Hanson et al., 2003), phloem-feeding aphids (Hanson et al. 2004).

\section{Selenium in soil-plant system}

\subsection{Selenium distribution in soil}

The global Se distribution in soils varies greatly from $0.005 \mathrm{mg} \mathrm{kg}^{-1}$ in Finland to $8,000 \mathrm{mg} \mathrm{kg}^{-1}$ in Tuva-Russia (Chasteen and Bentley, 2002). Although Se concentrations are in normal range

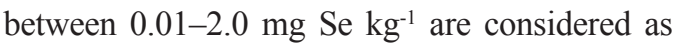
Se deficient soils; mean of world is about $0.4 \mathrm{mg}$ Se kg-1 and concentrations $>1,200 \mathrm{mg} \mathrm{Se} \mathrm{kg}^{-1}$ can occur in seleniferous soils (Fordyce, 2005).

Selenium occurrence in agroecosystems is related to natural and anthropogenic process. In relation with natural process, $\mathrm{Se}$ is associated with volcanic eruptions, weathering and evaporation in the process of soil formation and alluvial deposition in soil (Haygarth, 1994). In fact, the persistence of $\mathrm{Se}$ in soil is associated with parent material, principal source of Se soil formation (Fernandez and Charlot, 2009). Igneous and volcanic rocks generally contain around $0.035 \mathrm{mg} \mathrm{kg}^{-1}$, whereas sedimentary rocks present concentration between 0.05-0.06 mg kg-1 (He et al. 2005). Sedimentary rocks represent the principal compounds of earth surface and their Se concentration is much higher than in igneous rocks (Fernandez and Charlot, 2009). This can be attributed to Se transfer to the atmosphere and hydrosphere during volcanic processes (Haug et al. 2007). On the other hand, early studies published by Lag and Steinnes, (1974) have reported that Se-supply from the sea via rain and snow and sulphuric acid-rich polluted rain was an important Se source. Thus, anthropogenic processes also generated inputs of Se in agroecosystems (He et al. 2005) as extraction and processing of various minerals, pharmaceutical manufactures, veterinary medicine, glassware manufacturing industry, electronics devices industry, lubricants manufacturers, etc. (Frankerberger and Benson, 1994; Wen and Carignan, 2007). It has been estimated that between $30 \%$ and $40 \%$ of total Se emissions to the atmosphere are due to human activities (Wen and Carignan, 2007), such as: extraction and processing of different elements (copper, zinc, uranium and phosphorus), the use of pesticides and the combustion of oil and coal. In the atmosphere, Se is transported associated to particulate matter (Bosco et al. 2005) and then it is deposited in the agroecosystems. In addition, the extensive uses of Se-containing fly ash as soil amendments (Dhillon and Dhillon, 2003) and the irrigation of cultivated soils with Se-contaminated waters (Lemly, 1998), have a major impact upon the selenium cycle. The selenium cycle in the agroecosystems is complex because Se has a broad range of oxidation states, from $\mathrm{Se}^{2-}$ (completely reduced) to $\mathrm{Se}^{6+}$ (completely oxidized), and can be transformed by both chemical and biological processes (Zhang et al. 2000). 


\subsection{Selenium deficient soil and plant nutrition}

Selenium deficient soils are characterized by low Se-content and limited availability. In most of soils, Se content is found between 0.01 and $2.0 \mathrm{mg} \mathrm{Se} \mathrm{kg}{ }^{-1}$ (Neal, 1995; Mayland 1994; Fordyce, 2007). Dhillon and Dhillon (2003) proposed that soils with concentrations below $0.1 \mathrm{mg} \mathrm{Se} \mathrm{kg}^{-1}$ of soil are described as Se deficient.

Selenium deficiency has been reported in a number of areas across the world, such as China, North America, New Zealand, Australia, Sweden and Finland (Gissel-Nielsen et al., 1984; Yläranta, 1985; Gupta and Gupta, 2000) which means that feed crops do not contain sufficient Se to meet animal requirements (Gupta and Watkinson, 1985). This Se deficiency has been related with important diseases as Keshan and Keshin-Beck, two endemic disease associated with a Se-deficiency, which are present in China and Siberia. Keschan disease is produced generally in children and woman of childbearing age and its symptoms are related with impairment of cardiac function, cardiac enlargement and arrhythmia (Xu et al. 1997). The diseases occurrence is involving Se and vitamin $\mathrm{E}$ deficiencies, and the presence of the Coxsackie B virus (Moreno-Reynes et al. 1998). KaschinBeck disease is an osteoarthropy, which manifests as enlarged joints, shortened fingers and toes, and in severe cases dwarfism and is attributable to Se and vitamin E deficiency (Coppinger and Diamond, 2001) and Iodine deficiency (Contempré et al. 1991). In addition, the low Se content in human diet also has been associated with different diseases such cardiovascular disease (Rayman, 2002), and dysfunction in immune systems (Bodoni et al., 2008).

\subsection{Selenium in crop grown in Chilean Andisols}

Se concentration in soil depends on geological source (parental rock) from which it derives and on biogeochemical processes. In volcanic soils, little is known about the specific interactions of Se oxyanions (predominant species of inorganic selenium in volcanic soils) and the mineralogical components specific to these soils (imogolite and allophane), which could be responsible of the low Se bioavailability (Fernandez-Martinez and Charlot, 2009). In addition, the organic matter has an important role in Se content in soil due to propensity for Se to be adsorbed to organic materials (Ander et al. 2010; Fordyce et al. 2010). According to a screening carried out by the Soil Service Laboratory of La Frontera University (Chile), in soils of the South of Chile amounts of Se range between 0.02 and $0.18 \mathrm{mg}$ $\mathrm{kg}^{-1}$ soil. This is an important fact due that Andisols soils in southern Chile represent around 60\% of agricultural soils. On the other hand, about $50 \%$ of the Chilean Andisols present a high soil acidity level, one of the main factors limiting agricultural production (Mora et al. 2005; 2006). Due to this fact, it is necessary to apply lime and gypsum and large amounts of $\mathrm{P}$ fertilizer (Mora et al. 1999). The application of lime to ameliorate soil acidity can be assumed to reduce Se sorption by soil (Ylaränta, 1983; 1990) and therefore, to increase Se uptake by plants. On the other hand, the use of fertilizers containing phosphate should be expected to raise selenite availability to plants, because in Andisols phosphate strongly competes with selenite by sorption sites (Barrow et al. 2005). Soil acidification can be accelerated over a few years under intensive agricultural systems, with the consequent increase of phytotoxic aluminum $\left(\mathrm{Al}^{3+}\right)$ in the 
soil exchange complex, as demonstrated by the relationship between $\mathrm{Al}$ saturation percentage and $\mathrm{pH}$ for Chilean Andisols (Mora et al. 2005). Thus, inorganic Se forms as sodium selenite is bound to soil constituents as clays, oxy-hydroxides of aluminum (Al), iron (Fe) or manganese $(\mathrm{Mn})$, remaining unavailable to plants (Cartes et al. 2005; Mora et al. 2008; Nakamaru and Altansuvd, 2014). As demonstrated in sorption experiments, selenite behaves like phosphate (Barrow et al. 2005) and therefore it is more stronger sorbed than selenate to the soil surfaces, thus becoming less bioavailable than selenate at equal rates of soil application (Cartes et al. 2005). However, sodium selenate could be leached at wet fall conditions. Competitive inhibition of selenate uptake and accumulation by sulfate has been extensively studied in solution or sand cultures (Bell et al. 1992; Kopsell and Randle, 1997; Zayed and Terry, 1992) and in soil experiments (Bañuelos and Meek, 1990; Yläranta, 1990). Two reasons drive research concerning the selenate-sulfate interactions in soils. First, selenate is more mobile than selenite in soil (Yläranta, 1991, Cartes et al. 2005). The other is related to the fact that sulfate competes with selenate for sorption sites since both of them might only form outer-sphere complexes with soil minerals (Zhang and Sparks, 1990; Jara et al. 2006).

\subsection{Selenium in human nutrition}

In relation to optimal Se status in human dietary, the Recommended Dietary Allowances (RDAs) indicates that $55 \mu \mathrm{g} \mathrm{Se}$ day $^{-1}$ is an adequate dose for adult men and women (RDAs, 2000). According to Rayman, (2004), based on the activity of the plasma selenoenzyme GSH-Px, several governments and international committees have recommended daily intakes varying from 30 to $85 \mu \mathrm{g} \mathrm{day}^{-1}$ in human diets. The benefits of Se to human health are not only associated with its antioxidant function, but also with an improvement of the immune system, cancer risk and HIV (Rayman, 2002), specially at supranutritional levels up to $125 \mu \mathrm{g} \mathrm{day}^{-1}$ in relation to the currently recommended intakes (Combs et al. 2001). Likewise, Se deficiencies in ruminant diets generate metabolic disorders like the white muscle disease, alterations of both the immune responses and the reproductive performance, among others (Ceballos and Wittwer, 1999; Wittwer, 2002). According with NRC (2000), daily intakes between 100 and $300 \mu \mathrm{g} \mathrm{kg}^{-1}$ of dry weight (DW) are adequate to achieve the requirements of beef and dairy cattle.Wittwer et al. (2002b) reported Se deficiencies in $83 \%$ of the forage samples of 12 dairy farms of Southern Chile.

The low Se concentration in forages of Bío-Bío, La Araucanía and Los Lagos Regions has been associated to a low GSH-Px activity in grazing cattle and horses (Ceballos et al. 1998; Laporte et al. 1998; Wittwer et al. 2002) and to the white muscle disease in Red Friesian calves (Contreras et al. 2005). For this reason, several efforts for enhancing the Se content in plants that are the bases to increase the Se content in human diet have been realized (Bañuelos et al. 2012; Chilimba et al. 2012; Acuña et al. 2013; Durán et al. 2013; Rahman et al. 2013).

\section{Selenium biofortification}

\subsection{Agronomic Biofortification by using inor- ganic Se fertilizers}

Agronomic biofortification, through the application of Se-fertilizers is widely applied in countries such as: Australia, USA, New Zealand, 
United Kingdom and Finland (Bañuelos et al. 2012). In this context, Finland government is pioneer in the application of inorganic Se fertilizer as a biofortification program (Broadley et al., 2006). In Africa, a national Farm Input Subsidy Program exists that includes the agronomic Se biofortification with Se (Chilimba et al. 2012), where it has been tested successfully in maize Se supplemented. Similarly, Se biofortification has been tested in other several plant crop species Triticum aestivum, (Hawkesford and Zhao 2007; Govasmark and Salbu, 2011; Hart et al. 2011); Triticum durum (Poblaciones et al. 2014), Pisum sativum, (Poblaciones et al. 2013); rice (Premarathna et al. 2012); lentil (Rahman et al. 2013); mushrooms (Bhatia et al. 2013).

In Chile, selenium enrichment of fertilizer applications across coated seeds or by foliar applications in crops has been described as an effective strategy in order to increase Se availability to plants and concomitantly to enhance its content in pastures with strengthening the antioxidant system against aluminum toxicity (Mora et al. 2008). The benefits by Se on higher plants appear to be strictly dependent on the availability of both essential, as sulfur (S) and phosphorous $(\mathrm{P})$, and toxic, as aluminum ( $\mathrm{Al})$, cadmium (Cd) and arsenic (As), elements in culture medium. Cartes et al. (2006) evaluated the effect of the simultaneous presence of selenite and $\mathrm{S}$ on the antioxidant Lolium perenne system. By increasing the levels of S, the GSH-Px activity decreased and the damage of the lipid membrane increased. As previously discussed, being Se transported inside the cell by $\mathrm{S}$ transporter and having this latter a higher affinity for $\mathrm{S}$, higher amounts of $\mathrm{S}$ than Se were uptaken in the presence of higher concentration of sulfate. Mora et al. (2008) evaluated the impact of the level of soil acidity and $\mathrm{P}$ fertilization on the antioxidant responses of selenite-treated white clover plants, and they showed that the application of P and lime increased the antioxidant ability of plants by activating peroxidase (POD) and ascorbate peroxidase (APX) enzymes and by decreasing the lipid peroxidation at shoot Se concentration

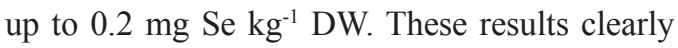
indicate that different combinations of soil acidity and P fertilization may influence Se absorption by plants and be responsible of beneficial or unfavorable effects of Se on lipid peroxidation, activation of POD and APX in white clover.

Andisols from southern Chile have high amounts of interchangeable $\mathrm{Al}$ and low $\mathrm{pH}$, properties that limit the Se-bioavailability in the soil solution (Mora et al. 1999; Mora and Demanet, 1999) and consequently the effectiveness of agronomic biofortification. Thus, inorganic selenite is bound to soil constituents, whereas selenate may be leached under wet fall conditions, limiting its availability to crops (Govasmark and Salbu, 2011; Hawkesford and Zhao, 2007). In addition, the Se transporters are similar to phosphorus or sulfur transporters, displayed in the low translocations rates to plants (Cartes et al. 2006; 2011). In fact, Inostroza-Blancheteau et al. (2012) showed that the high Se doses induce differentiation in wheat genotypes in terms of Se accumulation associated with highest expression level of sulfate transporters and lowest SOD activity.

\subsection{Biofortification by using microorganisms}

Microorganisms, mainly bacteria, play essential functions to plant growth, nutrition and disease control in agricultural systems (Nannipieri et al. 2003, Hawkes et al. 2007). Nowadays, studies have proposed the use of plant growth-promoting 
bacteria (PGPB) as alternative to enhance the uptake of micronutrients by plants (Tariq et al. 2007). Several reports showed the utilization of PGPB with abilities to mobilizing diverse micronutrients such as: Zinc ( $\mathrm{Zn})$, Iron (Fe), Manganese $(\mathrm{Mn})$, Copper $(\mathrm{Cu})$ and Selenium (Se) as biofortification strategies (Table 1).

Table 1. Diversity of PGPB used as a strategy of biofortification in plants

\begin{tabular}{|c|c|c|c|}
\hline Bacteria & Nutrient & Plants & References \\
\hline Pseudomonas sp. & $\mathrm{Fe}$ & Vignaradiate & Sharma et al. 2003 \\
\hline Pseudomonas fluorescens & $\mathrm{Zn}$ & Triticum aestivum & Sirohi et al. 2015 \\
\hline Trichoderma asperellum $\mathrm{T} 34$ & $\mathrm{Fe}$ & Lupinus albus & de Santiago et al. 2009 \\
\hline Penicillium chrysogenum & $\mathrm{Fe}$ & & Hördt et al. 2000 \\
\hline Pseudomonas sp. GRP3A & $\mathrm{Fe}$ & Zea mays & Sharma and Johri, 2003 \\
\hline \multirow[t]{4}{*}{ Trichoderma asperellum $\mathrm{T} 34$} & $\mathrm{Fe}$ & Triticum aestivum & de Santiago et al. 2010 \\
\hline & $\mathrm{Cu}$ & & \\
\hline & $\mathrm{Mn}$ & & \\
\hline & $\mathrm{Zn}$ & & \\
\hline Bacillus sp. AW1 & $\mathrm{Cu}$ & Triticum aestivum & Rana et al. 2012 \\
\hline \multirow[t]{3}{*}{ Providencia sp. AW5, Brevundimonas sp. AW7 } & $\mathrm{Zn}$ & & \\
\hline & $\mathrm{Fe}$ & & \\
\hline & $\mathrm{Mn}$ & & \\
\hline Achromobacter xylosoxidans strain $\mathrm{Ax} 10$ & $\mathrm{Cu}$ & Brassica juncea & Ma et al. 2009 \\
\hline Rhizobacteria N.D & $\mathrm{Mn}$ & Triticum aestivum & Marschner et al. 1991 \\
\hline Arthrobacter sp. & $\mathrm{Fe}$ & Glycine max & Nogueira et al. 2007 \\
\hline Variovorax sp. & $\mathrm{Mn}$ & & \\
\hline \multicolumn{4}{|l|}{ Ralstonia sp. } \\
\hline Azotobacter chroococcum, Azospirillum brasilense & $\mathrm{Zn}$ & Triticum aestivum & Ebrahim and Aly 2004 \\
\hline Enterobacter sp. B16 & $\mathrm{Se}$ & Triticum aestivum & Acuña et al. 2013 \\
\hline \multicolumn{4}{|l|}{ Stenotrophomonas sp. B19 } \\
\hline Enterobacter sp. B16 & $\mathrm{Se}$ & Triticum aestivum & Duran et al. 2013 \\
\hline \multicolumn{4}{|l|}{ Stenotrophomonas sp. B19 } \\
\hline \multicolumn{4}{|l|}{ Pseudomonas sp. R12 } \\
\hline \multicolumn{4}{|l|}{ Bacillus sp. R8 } \\
\hline Bacillus sp. E5 & $\mathrm{Se}$ & Triticum aestivum & Duran et al. 2014 \\
\hline \multicolumn{4}{|l|}{ Acinetobacter sp. E6.1 } \\
\hline Klebsiella sp. E2 & & & \\
\hline
\end{tabular}


Selenium in the agroecosystems is found in both inorganic and organic forms. The inorganic Se forms are present in four oxidation states, which are denoted as selenide $\left(\mathrm{Se}^{2-}\right)$, elemental $\mathrm{Se}\left(\mathrm{Se}^{0}\right)$, selenite $\left(\mathrm{Se}^{4+}\right)$ and selenate $\left(\mathrm{Se}^{6+}\right)($ Fernandez-Martinez and Charlot, 2009). It is widely accepted that bacteria have capability to reduce oxidized and methylated Se oxyanions to some different Se-compounds. The reduction processes have been described as the ability of these microorganisms to convert the $\mathrm{Se}^{6+}$ and $\mathrm{Se}^{4+}$, to $\mathrm{Se}^{0}$ and finally generating Se methylated compounds (Losi and Frankerberger, 1996) and organic Se compounds as SeMet and SeMeSeCys (Duran 2015, under revision). Thus, biofortification by using microorganisms as alternatives to the chemical fertilization and the agronomic practices have gained great interest for researchers. Table 2 summarizes different studies related with Se biofortification.

Table 2. Selenium biofortification of crops

\begin{tabular}{|c|c|c|c|c|}
\hline Fertilization methods & Se source & Plants & Results & References \\
\hline Seed pelletization & Sodium selenite & Trifolium repens L. cv. Nusiral & Enhanced SOD activity & Mora et al. 2008 \\
\hline $\begin{array}{l}\text { Se enrichment nutrients } \\
\text { solutions }\end{array}$ & Sodium selenite & Lolium perenne L.cv. Nui & Decreased TBARS & Cartes et al. 2010 \\
\hline $\begin{array}{l}\text { Se enrichment nutrients } \\
\text { solutions }\end{array}$ & Sodium selenite & $\begin{array}{l}\text { Triticum aestivum } \text { L. cv. Puelche Triticum } \\
\text { aestivum } \text { L. cv. Tito } \\
\text { Triticum aestivum } \text { L. cv. Kumpa }\end{array}$ & $\begin{array}{l}\text { Se-tolerant wheat genotype, } \\
\text { enhanced antioxidant } \\
\text { activities }\end{array}$ & $\begin{array}{l}\text { Inostroza- } \\
\text { Blancheteau et } \\
\text { al.2012 }\end{array}$ \\
\hline Seedpelletization & Sodium selenite & $\begin{array}{l}\text { Lolium perenne L.cv. Nui } \\
\text { Lolium perenne L.cv. Aries } \\
\text { Lolium perenne L.cv. Quartet }\end{array}$ & $\begin{array}{l}\text { Improve the antioxidant } \\
\text { systems }\end{array}$ & Cartes et al. 2011 \\
\hline Fertigation & $\begin{array}{l}\text { Sodium selenite } \\
\text { Sodium selenate }\end{array}$ & Lolium perenne L.cv. Aries & Decreased TBARS & Cartes et al. 2005 \\
\hline Fertigation & Sodium selenite & Lolium perenne L.cv. Aries & $\begin{array}{l}\text { Reduction of GSH-Px } \\
\text { activity }\end{array}$ & Cartes et al. 2006 \\
\hline Fertigation & Sodium selenate & $\begin{array}{l}\text { Triticum aestivum } \mathrm{L}, \text { Zea mays, Glycine } \\
\text { max, Solanum tuberosum, Brassica napus, } \\
\text { Brassica oleracea }\end{array}$ & $\begin{array}{l}\text { Enhanced selenium content } \\
\text { in edible parts }\end{array}$ & Mao et al. 2014 \\
\hline Inoculation root & Selenobacteria & Triticum aestivum L. cv. Puelche & $\begin{array}{l}\text { Enhanced selenium content } \\
\text { in grain }\end{array}$ & Duran et al. 2013 \\
\hline Inoculation root & Selenobacteria & Triticum aestivum L. cv. Fritz & $\begin{array}{l}\text { Enhanced selenium content } \\
\text { in shoot }\end{array}$ & Acuña et al. 2013 \\
\hline Seed pelletization & $\begin{array}{l}\text { Endophytic } \\
\text { Selenobacteria }\end{array}$ & Triticum aestivum L. cv. & $\begin{array}{l}\text { Enhanced selenium content } \\
\text { in shoot }\end{array}$ & Duran et al. 2014 \\
\hline
\end{tabular}




\subsubsection{Rhizospheric bacteria for Se biofortifica-} tion

Selenobacteria have been described as Se-respiring and Se-tolerant bacteria, associated to assimilation and metabolization mechanisms inside the cells (Kessi et al. 1999; Losi and Frankerberger, 1997; Stolz et al. 1999). Diverse studies showed that bacteria belonging to Firmicutes (Bacillus and Paenibacillus) and Proteobacteria (Pseudomonas and Enterobacter) stimulate Se transformation through oxidation, reduction and methylation from selenium contaminated soil called "selenifeorus soil" (Losi and Frankenberger 1997; Fordyce 2007; Fernandez-Martinez and Charlot, 2009). Studies by Acuña et al. (2013) showed that selenium deficient soils as Andisols possess a high diversity of culturable bacteria with the capabilities to metabolize and tolerate high Se doses. In Chile, there are about 5.1 million has of volcanic soils and about half of this area occurs under agricultural use, where the most important national milk, meat and cereal crops are produced (ODEPA, 2014).

Cereals, mainly wheat (Triticum aestivum L.), have been described as a good source for bioavailable Se, being SeMet its principal organic form in grain (Lyons et al., 2004). Broadley et al. (2006) have demonstrated the stronger link between the Se concentration of wheat grain and the optimal Se status in human diet (Broadley et al. 2006). Recent studies have demonstrated that the inoculation with Se-enriched selenobacteria increased the Se concentration in plant tissue of wheat (Acuña et al. 2013). Similarly, studies conducted by Duran et al., (2013) evaluated the synergism between selenobacteria and AMF in Se uptake and translocation in wheat plants. This report showed that plants co-inoculated with a mixture of selenobacteria strains and G. claroideum increased significantly the Se content in grain. Figure 1 shows the schematic representation of Se biofortification in Andisols (high Al saturation) of wheat plants by using bacteria, where seeds were coated with Se enriched bacteria and where the main Se forms found were elemental Se (Selenonanosphere), SeMet and SeMeSeCys. Wheat plants are able to improve the antioxidant activity and to enhance the Se content in shoots and grain to obtain enriched flour (Acuña et al. 2013; Durán et al. 2014, Durán data no shown)

\subsubsection{Endophytic bacteria for Se biofortification}

In a recent study, Durán et al. (2014) showed that plant growth promoting (PGP) endophytic bacteria Bacillus sp.E5 and Acinetobacter sp. E6.2 have ecological advantage over rhizospheric bacteria in terms of Se tolerance (Durán et al. 2014; Etesami et al. 2014). It should also be kept in mind that endophytes are better adapted to elevated Se concentration than rhizospheric bacteria. Indeed, rhizobacteria can only tolerate around $20 \mathrm{mM}$ of sodium selenite (Acuña et al. 2013), whereas our endophytic strains showed tolerance to $60-180 \mathrm{mM}$ of Se. Bacteria strains were tagged with Green Fluorescent Protein and were observed by confocal microscopy inside the root plant (Figure $2 \mathrm{~b}, \mathrm{c}$ ). In this study also was evaluated the effect of arbuscular mycorrhizal fungi which enhance the Se content in plants and improve the antioxidant system in wheat (Figure 2d). Elevated Se tolerance by bacteria also was reported by Hunter and Manter (2009) for Pseudomonas sp. (150 mM Se). In addition, recently our research team showed that Bacillus sp.E5 and Acinetobacter sp.E6.2 exhibit mainly stable intracellular and extracellular NanoSe and important Se organic forms as seleno methyl selenocysteine 
(SeMeSeCys) and selenomethionine (SeMet), (Durán fata no shown), the three most important Se forms for cancer prevention. Similarly, in Lactuca sativa plants the enhancing of Se content in edible tissue and the performance of physiological parameters and scavenging reactive oxygen species for counteract the effect of drought stress were corroborated (Durán et al., 2015, submitted). Under field conditions similar benefit effects were found, as Se supplemented plants showed elevated SeMet in grain (dates in preparation).

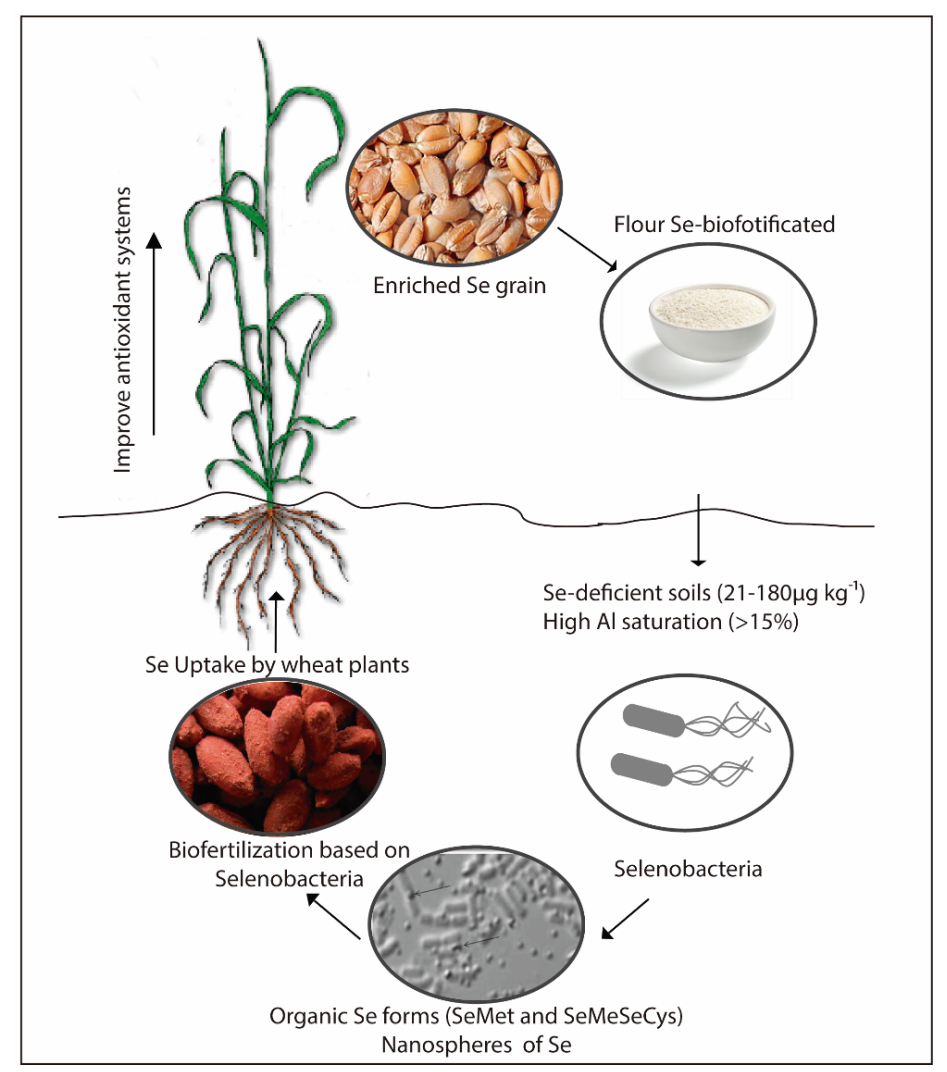

Figure 1. Selenium biofortification by using microorganisms in Andisols. Selenobacteria reduce inorganic Se into Nanospheres and other organic Se forms. The microbial inocula can be coated in seed and wheat plant enhances the Se content in wheat grain for obtaining Se biofortified flour. 

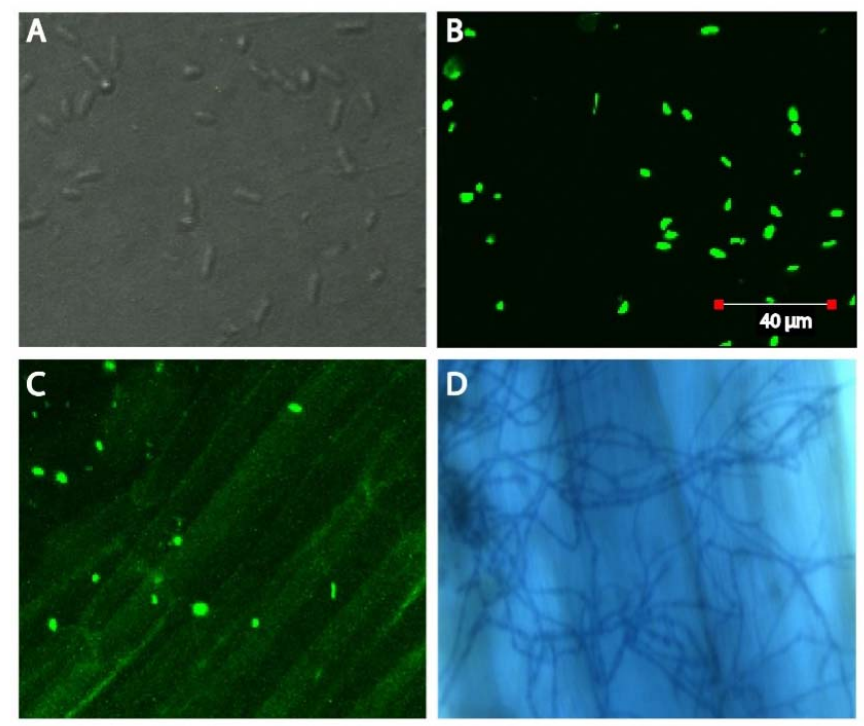

Figure 2. Confocal laser scanning microscopy images of endophytic colonization: (A) control bacteria without Gfp tagged, (B) Gfp tagged bacteria, (C) root of wheat plants colonized by bacteriaGfp tagged and (F) optical microscopy image of root of wheat plants colonized by mycorrhiza

\section{Conclusions and future perspectives}

The use of selenium pelleted seeds appears to be an interesting alternative to ameliorate selenium deficiencies in grasslands systems. Similarly, the co-inoculation of selenobacteria mixture and arbuscular mycorrhizal fungi represents a promising strategy for biofortification of wheat plants in order to produce Se enriched flour for supplementing foods for human consumption. Further studies are needed to confirm the effectiveness of biofertilization strategy under field conditions and to elucidate the main mechanisms of Se uptake by plants.

\section{Acknowledgments}

The authors acknowledged the important contribution of National Commission for scientific and technological Research (CONICYT) Program MEC 80130066 of Atraction an Integration of Advance Human Capital (Dr. Liliana Gianfreda) and the technical support of Scientific and Technological Bioresource Nucleus (BIOREN) from La Frontera University. 


\section{References}

Acuña, J.J., Jorquera, M.A., Barra, P.J., Crowley, D.E., Mora, M.L. 2013. Selenobacteria selected from the rhizosphere as a potential tool for Se biofortification of wheat crops. Biol. Fertil. Soils. 49, 175-185.

Ander, E.L. Fordyce, F.M. Johnson, C.C. Schofield, D.I. 2010. Controls on the distribution of selenium in the soils of East Anglia, UK. In: Joint meeting : Northeastern \& Southeastern : 45th Annual Meeting of the Northeastern Section, GSA. Baltimore, USA, Geological Society of America, 143.

Bañuelos, G.S., Meek, D.W. 1990. Accumulation of selenium in plants grown on selenium-treated soil. J Environ Qual. 19, 772-777.

Bañuelos, G.S., Stushnoff, C., Walse, S.S., Zuber, T., Yang, S.I., Pickering, I.J., Freeman, J.L. 2012. Biofortified, selenium enriched, fruit and cladode from three Opuntia Cactus pear cultivars grown on agricultural drainage sediment for use in nutraceutical foods. Food. Chem. 135, 9-16.

Barrow N.J., Cartes P., Mora, M.L. 2005. Modifications to the Freundlich equation to describe anion sorption over a large range and to describe competition between pairs of ions. Eur. J. Soil. Sci. 56, 601-606.

Bell, P.F., Parker, D.R., Page, A.L. 1992. Contrasting selenate-sulfate interactions in selenium accumulating and nonaccumulating plant species. Soil Sci. Soc. Am. J. 56, 1818-1824.

Bhatia, P., Aureli, F., D'Amato, M., Prakash, R., Cameotra, S.S., Nagaraja, T.P., Cubadda, F. 2013. Selenium bioaccessibility and speciation in biofortified Pleurotus mushrooms grown on selenium-rich agricultural residues. Food Chem. 140, 225-30.
Bordoni, A., Danesi, F., Malaguti, M., Di Nunzio, M., Pasqui, F., Maranesi, M., Biagi, P . 2008. Dietary Selenium for the counteraction of oxidative damage: fortified foods or supplements? Brit. J. Nutr. 99, 191-197.

Bosco, M.L., Varrica, D., Dongarra, G. 2005. Case study: inorganic pollutants associated with particulate matter from an area near a petrochemical plant. Environ. Res. 99, 18-30.

Cartes, P., Gianfreda, L., Mora, M.L. 2005. Uptake of selenium and its antioxidant activity in ryegrass when applied as selenate and selenite forms. Plant Soil. 276, 359-367.

Cartes, P., Shene, C., Mora, M.L. 2006. Selenium distribution in ryegrass and its antioxidant role as affected by sulfur fertilization. Plant Soil. 285, 187-195.

Cartes, P., Gianfreda, L., Paredes, C., Mora, M.L. 2011. Selenium uptake and its antioxidant role in ryegrass cultivars as affected by selenite seed pelletization. J. Soil. Sci. Plant Nutr. 11, 1-14.

Chasteen, T.G., Bentley, R. 2003. Biomethylation of selenium and tellurium: microorganisms and plants. Chem Rev. 103, 1-25.

Ceballos, A., Wittwer, F.G., Contreras, P.A., Quiroz, E., Böhmwald. H. 1999. Actividad de glutatión peroxidasa en bovinos a pastoreo correlacionada con la concentración sanguínea y plasmática de selenio. Pesq. Agrop. 34, 2331-2338.

Chilimba, A.D.C., Young, S.D., Black, C.R., Meacham, M.C., Lammel, J., Broadley, M.R. 2012. Agronomic biofortification of maize with selenium in Malawi. F. Crop. Res. 125, 118-128.

Combs, G.F. 2001. Selenium in global food systems. Br. J. Nutr. 85, 517-857.

Contempré, B., Dumont, J.E., Ngo, B., Thilly, CH., Diplock, A.T., Vanderpas, J. 1991. Effect of selenium supplementation in hypothyroid subjects of 
an iodine and selenium deficient area: the possible danger of indiscriminate supplementation of iodine-deficient subjects with selenium. J. Clin. Endocrinol. Metab. 73, 213-215.

Coppinger, R.J., Diamond, A.M. 2001. Selenium deficiency and human disease. In Selenium: Its Molecular Biology and Role in Human Health, .D.L Hatfield, editor. Dordrecht, The Netherlands: Kluwer Academic Publishers. pp. 219233.

de Souza, M.P., Chu, D., Zhao, M., Zayed, A.M., Ruzin, S.E., Schichnes, D., Terry, N. 1999. Rhizosphere bacteria enhance selenium accumulation and volatilization by Indian Mustard. Plant Physiol. 119, 565-573.

Dhillon, K.S., Dhillon, S.K. 2003. Distribution and management of seleniferous soils. In: Sparks D (ed) Advances in agronomy, Elsevier, Amsterdam 119-184.

Djanaguiraman, M., Durga, D.D., Shanker, A.K., Sheeba, J.A., Bangarusamy, U. 2005. Selenium, an antioxidative protectant in soybean during senescence. Plant Soil. 272, 77-86.

Dodig, S., Cepelak, I. 2004. The facts and controversies about selenium. Acta harm. 54, 261-276.

Durán, P., Acuña, J.J., Jorquera, M.A., Azcón, R., Borie, F., Cornejo, P., Mora, M.L. 2013. Enhanced selenium content in wheat grain by co-inoculation of selenobacteria and arbuscularmycorrhizal fungi: A preliminary study as a potential Se biofortification strategy. J. Cereal Sci. 275-280.

Durán, P., Acuña, J.J., Jorquera, M.A., Azcón, R., Paredes, C., Rengel, Z., Mora, M.L. 2014. Endophytic bacteria from selenium-supplemented wheat plants could be useful for plant-growth promotion, biofortification and Gaeumannomycesgraminis biocontrol in wheat production. Biol. Fertil. Soils. 50, 983-990.
Etesami, H., Mirseyed Hosseini, H., Alikhani, H.A. 2014. In planta selection of plant growth promoting endophyticbacteria for rice (Oryza sativa L.). J. Soil. Sci. Plant Nutr. 14 (2), 491-503.

Facompre, N., El-Bayoumy, K. 2009. Potential stages for prostate cancer prevention with selenium: implications for cancer survivors. Cancer Res. 69, 2699-2703.

Fernandez-Martinez, Charlot L. 2009. Selenium environmental cy- cling and bioavailability: a structural chemist point of view. Rev Environ Sci. Biotechnol. 8, 81-110.

Filek, M., Keskinen, R., Hartikainen, H., Szarejko, I., Janiak, A., Miszalski, Z., Golda, A. 2008. The protective role of selenium in rape seedlings subjected to cadmium stress. J. Plant Physiol. 165, 833-844

Fordyce, F. 2005. Selenium deficiency and toxicity in the environment. In 'Essentials of medical geology - Impacts of the natural environment on public health' (Eds O Selinus, B Alloway, JA Centeno, RB Finkelman, R Fuge, U Lindh, P Smedley) Elsevier - Academic Press, London. pp. 373-415.

Fordyce, F. 2007. Selenium geochemistry and health. Ambio. 36, 94-97.

Fordyce, F.M., Brereton, N., Hughes, J., Luo, W., Lewis, J. 2010. An initial study to assess the use of geological parent materials to predict the Se concentration in overlying soils and in five staple foodstuffs produced on them in Scotland. Sci. Tot. Environ. 408, 5295-5305.

Frankerberger, W.T., Benson, S. 1994. Preface . In Selenium in the Environment. W.T Frankerberger., S Benson editors. Marcel Dekker Inc. 3-5.

Germ, M., Stibilj, V., Kreft, I. 2005. Metabolic Importance of Selenium for Plants. Eur. J. Plant Sci. Biotech. 1, 91-97. 
Gissel-Nielsen, G., Gupta, U.C., Lamand, M., Westermarck, T. 1984. Selenium in soils and plants and its importance in livestock and human nutrition. Adv. Agron. 37, 397-460.

Govasmark, E., Salbu, B. 2011. Translocation and re-translocation of selenium taken up from nutrient solution during vegetative growth in spring wheat. J. Sci. Food Agric. 91, 1367-1372.

Gupta, U.C., Gupta, S.C. 2000. Selenium in soils and crops, its deficiencies in livestock and humans: Implications for management. Commun. Soil Sci. Plant Anal. 31, 1791-1807.

Gupta, U.C., Watkinson, J.H. 1985. Agricultural significance of selenium. Outlook Agric. 14, 183189.

Hanson, B., Garifullina, G.F., Lindblom, S.D., Wangeline, A., Ackley, A., Kramer, K., Norton, A.P., Lawrence, C.B., Pilon-Smits, E.A.H. 2003. Selenium accumulation protects Brassica juncea from invertebrate herbivory and fungal infection. New Phytol. 159, 461-469.

Hanson, B., Lindblom, S.D., Loeffler, M.L., PilonSmits, E.A.H. 2004. Selenium protects plants from phloem-feeding aphids due to both deterrence and toxicity. New Phytol. 162, 655-662.

Hart, D.J., Fairweather-Tait, S.J., Broadley, M.R., Dickinson, S.J., Foot, I., Knott, P., McGrath, S.P., Mowat, H., Norman, K., Scott, P.R., Stroud, J.L., Tucker, M., White, P.J., Zhao, F.J., Hurst, R. 2011. Selenium concentration and speciation in biofortified flour and bread: Retention of selenium during grain biofortification, processing and production of Se-enriched food. Food Chem. 126, 1771-1778.

Hartikainen, H., Ekholm, P., Piironen, V., Xue, T., Koivu, T. and Yli-Halla, M. 1997. Quality of the ryegrass and lettuce yields as affected by selenium fertilization. Agr. Food Sci. Fin. 6, 381-387
Hartikainen, H. 2005. Biogeochemistry of selenium and its impact on food chain quality and human health. J. Trace Elem. Med. Biol. 18, 309-318.

Haug, A., Graham, RD., Christophersen, O., Lyons, G.H. 2007. How to use the world's scarce selenium resources efficiently to increase the selenium concentration in food. Microb. Ecol. Health. 19, 209-228.

Hawkesford, M.J., Zhao, F.J. 2007. Strategies for increasing the selenium content of wheat. J. Cereal Sci. 46, 282-292.

Haygarth, P.M., Fowler, D., Sturup, S., Davison, B.M., Jones, K.C. 1994. Determination of gaseous and particulate selenium over a rural grassland in the UK. Atmos. Environ. 28, 3655-3663.

He, ZL.,Yang , X.E., Stofella, P. 2005. Trace elements in agroecosystems and impacts on the environment. J. Trace Elem. Med. Biol. 19, 125-140.

Heijari, J., Kivimäenpää, M., Hartikainen, H., Julkunen-Tiitto, R., Wulff, A. 2006. Responses of strawberry (Fragaria $\mathrm{x}$ ananassa) to supplemental UVBradiation and selenium under field conditions. Plant Soil. 282, 27-39.

Ingh, M. 2005. A Review on Phytoremediation of Heavy Metals and utilization of its Byproducts. Appl. Ecol.Env. Res 3, 1-18.

Jara, A.,Violante, A. Máximo, P., Mora, M.L. 2006. Mutual Interactions of sulfate, oxalate, citrate and phosphate on synthetic and natural allophanes. Soil Sci. Soc. Am. J. 70, 337-346.

Kopsell, D.A., Randle, W.M. 1997. Selenate concentration affects selenium and sulfur uptake and accumulation by 'Granex 33' onions. J Amer. Soc. Hort. Sci. 122, 721-726.

Korlhe, J., Brigelius-Flohé, R., Bock, A., Gaertner, R., Meyer, O., Flohé, L. 2000. Selenium in biology. Biol. Chem. 381, 849-864. 
Lang, J., Steinnes, E. 1974. Soil selenium in relation with precipitation. Ambio. 3, 237-238.

Lemly, A.D. 1998. A position paper on selenium ecotoxicology: A procedure for deriving site-specific water quality criteria. Ecotoxicol. Environ.Saf. 1, 259-266.

Mao, J., Wang, Z., Zan, Y., Lyons, G., Zou, C. 2014. Using agronomic biofortification to boost zinc, selenium, and iodine concentrations of food crops grown on the loess plateau in China. J. Soil. Sci. Plant Nutr. 14 (2), 459-470.

Mayland, H.F. 1994. Selenium in plant and animal nutrition. In: W.T. Jr. Frankenberger and S. Benson (eds.), Selenium in the Environment. Marcel Dekker Inc., New York, pp. 29-45.

Méplan, C., Hesketh, J. 2012. The influence of selenium and selenoprotein gene variants on colorectal cancer risk. Mutagenesis. 27, 177-186.

Miller, J.K., Brzezinska-Slebodzinska E., Madsen F.C. 1993. Oxidative stress, antioxidants, and animal function. J. Dairy Sci.76 (9), 2812-2823.

Mittler, R., Zilinskas, B.A. 1991. Purification and characterization of pea cytosolic ascorbate peroxidase. Plant Physiol. 97, 962-968.

Mora, M.L., Baeza, G., Pizarro, C., Demanet, R. 1999. Effect of calcitic and dolomitic lime on physico-chemical properties of a Chilean Andisols Commun Soil Sci.Plan.An. 30 (3-4), 427-439.

Mora, M.L., Alfaro, M.A., Jarvis, S.C., Demanet, R., Cartes, P. 2006. Soil aluminium availability in Andisols of southern Chile and its effect on forage production and animal metabolism. Soil Use Man. 22, 95-101

Mora, M.L. Pinilla, L., Rosas, A., Cartes, P. 2008. Selenium uptake and its influence on the antioxidative system of white clover as affected by lime and phosphorus fertilization. Plant Soil. 303, 139-149.
Moreno-Reynes, R., Suetens, C., Mathieu, F., Begaux, F., Zhu, D., Rivera, MT., Boelaert, M., Nève, J,,Perlmutter, N., Vanderpas, J. 1998. KashinBeck osteoarthropathy in rural Tibet in relation to selenium and iodine status. New Eng. J. Med. $339,1112-1120$.

Nakamaru, Y.M., Altansuvd, J. 2014. Speciation and bioavailability of selenium and antimony in non-flooded and wetland soils: a review. Chemosphere. 111, 366-371.

Neal, R.H. 1995. Selenium, in Heavy metals in soils, Alloway B.J. (ed). second edition, Blackie Academic and Professional, London, 12, 260-262.

O’Toole, D., Raisbeck, M.F. 1995. Pathology of experimentally induced chronic selenosis (alkali disease) in yearling cattle. J. Vet .Diagn. Invest. 7, 364-373.

Pedrero, Z., Madrid, Y., Hartikainen, H., Cámara, C. 2008. Protective effect of selenium in broccoli (Brassica oleracea) plants subjected to cadmium exposure. J. Agr. Food Chem. 56, 266-27.

Pennanen, A., Xue, T., Hartikainen, H. 2002. Protective role of selenium in plant subjected to severe UV irradiation stress. J. Appl. Bot. 76, 66-76.

Pilon-Smits, E A., Quinn, C.F., Tapken W., Malagoli, M, Schiavon, M. 2009. Physiological functions of beneficial elements. Curr Opin Plant Biol 12, 267-274.

Poblaciones, M.J., Rodrigo, S.M., Santamaría, O. 2013. Evaluation of the potential of peas (Pisumsativum L.) to be used in selenium biofortification programs under mediterranean conditions. Biol. Trace Elem. Res. 151, 132-137.

Poblaciones, M.J., Rodrigo, S., Santamaría, O., Chen, Y., McGrath, S.P. 2014. Agronomic selenium biofortification in Triticum durum under Mediterranean conditions: From grain to cooked pasta. Food Chem. 146, 378-384. 
Premarathna, L., Mclaughlin, M.J., Kirby, J.K., Hettiarachchi, G.M., Stacey, S., Chittleborough, D.J. 2012. Selenate-Enriched Urea Granules Are a Highly Effective Fertilizer for Selenium Biofortification of Paddy Rice Grain. J. Agric. Food Chem. 60, 6037-6044.

Rahman, M.M., Erskine, W., Zaman, M.S., Thavarajah, P., Thavarajah, D., Siddique, K.H.M., 2013. Selenium biofortification in lentil (Lens culinaris Medikus sub sp. culinaris): Farmers' field survey and genotype $\mathrm{x}$ environment effect. Food Res. Int. 54, 1596-1604.

Rayman, M.P. 2000. The importance of selenium to human health. Lancet. 356, 233-241.

Rayman, M.P. 2002. The argument for increasing selenium intake. Proc.Nutr. Soc. 61, 203-215.

Rayman, M.P. 2004. The use of high-selenium yeast to raise selenium status: how does itmeasure up? Br. J. Nutr. 92, 557-573.

Rayman, M.P. 2008. Food-chain selenium and human health: emphasis on intake. Br. J. Nutr., 100, 254-268.

Sabeh, F., Wright, T., Norton, S.J. 1993. Purification and characterizationof a glutathione peroxidase from the Aloe vera plant. Enzymeprotein. 47, 279-285.

Seppänen, M., Turakainen, M., Hartikainen, H. 2003. Selenium effects on oxidative stress in potato. Plant Sci. 165, 311-319.

Schomburg, I., Chang, A., Ebeling, C., Gremse, M., Heldt, C., Huhn, G., Schomburg, D. 2004. BRENDA, the enzyme database: updates and major new developments. Nucleic Acids Res. $32,431-433$

Singh, M., Singh, H., Bhandari, D.K. 1980. Interaction of selenium and sulphur on the growth and chemical composition of raya. Soil Sci., 129, 238-244.
Sirohi, G., Upadhyay, P., Shankar Srivastava, P., Srivastava, S. 2015. PGPR mediated Zinc biofertilization of soil and its impacton growth and productivity of wheat. J. Soil. Sci. Plant Nutr. 15 (1), 202-216.

Turakainen, M., Hartikainen, H., Ekholm, P., Seppänen, M.M. 2006. Distribution of selenium in different biochemical fractions and raw darkening degree of potato (Solanum tuberosum) tubers supplemented with selenate. Agr. Food Chem. 54, 8617-8622.

Wen, HJ., Carignan, J. 2007. Reviews on atmospheric selenium: emissions, speciation and fate. Atmos. Environ. 41, 7151-7165.

Wittwer, A.P, Ceballos, A., Contreras, P., Andaur, M., Bohwald, H. 2002.Actividad de glutatión peroxidasa (GSH-Px) en sangre de bovinos a pastoreo de la IX Región, Chile y su relación con la concentración de selenio en el forraje. Arch. Med. Vet. 34, 49-57.

Xu, GL., Wang, SC., Gu, B.Q. 1997. Further Investigation on the role of selenium deficiency in the patetiology and pathogenesis of Keshan disease. Biomed Environ. Sci. 10, 316-26.

Xue, T., Hartikainen, H., Piironen, V. 2001. Antioxidative and growth-promoting effect of selenium on senescing lettuce. Plant Soil. 237, 55-61.

Yläranta, T. 1983. Sorption of selenite and selenate added in the soil. Ann. Agr. Fenn. 22, 9-39.

Yläranta, T. 1990. The selenium content of some agricultural crops and soils before andafter the addition of selenium to fertilizers in Finland. Ann. Agric. Fenn. 29, 131-139.

Yläranta, T. 1991. Effects of the addition of sulphate and phosphate on the leaching of selenite and selenate in acidic soils. Ann AgrFenn 30, 311-319.

Zayed, A.M., Terry, N. 1992. Selenium volatilization in broccoli as influenced by sulfate supply. J Plant Physiol. 140, 646-652. 
Zhang, P., Sparks, D.L. 1990. Kinetics of selenate and selenite adsorption/desorption at the goethite/water interface. Environ Sci. Technol. 24, 1848-1856

Zhang, P., Sparks, D.L. 1990. Kinetics and mechanisms of sulfate adsorption/desorption on goethite using pressure-jump relaxation. Soil Sci.Soc Am. J. 54, 1266-1273.
Zhang, Y.Q., Frankenberger, W.T. 2000. Formation of dimethylselenonium compound in soil. Environ. Sci. Technol. 5,776-783. 